\title{
Molecular Regulation of Ghrelin Expression by Pro-Inflammatory Cytokines TNF- $\alpha$ and IL-6 In Rat Pancreatic AR42J Cell Line
}

\author{
Kah-Meng Lao \\ Department of Biomedical Science, Faculty of Science, Universiti Tunku Abdul Rahman \\ Jalan Universiti, Bandar Barat, 31900 Kampar, Perak, Malaysia \\ E-mail: michelle.kahmeng@gmail.com
}

\section{Wyi-Sian Lim}

Department of Biomedical Science, Faculty of Science, Universiti Tunku Abdul Rahman Jalan Universiti, Bandar Barat, 31900 Kampar, Perak, Malaysia

E-mail: lim_ws@ymail.com

\section{Di-Lin Ng}

Department of Biological Science, Faculty of Science, Universiti Tunku Abdul Rahman Jalan Universiti, Bandar Barat, 31900 Kampar, Perak, Malaysia

E-mail: ngdl@utar.edu.my

\section{Tengku-Sifzizul Tengku-Muhammad}

Department of Biological Science, Faculty of Science and Technology, Universiti Malaysia Terengganu, 21030 Kuala Terengganu, Terengganu, Malaysia

E-mail: sifzizul@umt.edu.my

\section{Quok-Cheong Choo}

Department of Biological Science, Faculty of Science, Universiti Tunku Abdul Rahman Jalan Universiti, Bandar Barat, 31900 Kampar, Perak, Malaysia

$$
\text { E-mail: chooqc@utar.edu.my }
$$


Choy-Hoong Chew (Corresponding author)

Department of Biomedical Science, Faculty of Science, Universiti Tunku Abdul Rahman Jalan Universiti, Bandar Barat, 31900 Kampar, Perak, Malaysia

Tel: 605-468-8888-4426Ｅ-mail: chewch@utar.edu.my

Received: August 28, 2012 Accepted: September 10, 2012

doi:10.5296/jbls.v4i1.2306 URL: http://dx.doi.org/10.5296/jbls.v4i1.2306

\begin{abstract}
Ghrelin is a 28 amino acid peptide endogenous ligand for growth hormone secretatgogue receptor (GHS-R) that functions to stimulate growth hormone, regulate inflammation, appetite and energy balance. However, the regulation of ghrelin expression by pro-inflammatory cytokines during inflammation process has never been investigated systematically. This study was carried out to investigate the effects of major pro-inflammatory cytokines such as TNF- $\alpha$ and IL-6 on ghrelin expression using AR42J rat pancreatic cell line as model system. The cells were treated with different concentrations of the cytokines for 24 hours. Real-Time RT-PCR, Western blot and densitometry analysis were carried out to quantify ghrelin mRNA and protein expression, respectively. Although TNF- $\alpha$ and IL-6 stimulation resulted in a general down-regulatory pattern in both mRNA and protein expression of ghrelin, stimulation with $5 \mathrm{ng} / \mathrm{ml}$ of TNF- $\alpha$ and IL-6 slightly induced the expression of ghrelin expression. However, higher doses of the cytokines ranging from $10-50 \mathrm{ng} / \mathrm{ml}$ suppressed the ghrelin expression in a dose-dependant manner. These results indicate that ghrelin in AR42J pancreatic cell line is regulated by the pro-inflammatory cytokines and that the dosages of the cytokines play an important factor in the regulation of the expression.
\end{abstract}

Keywords: Ghrelin, Expression, TNF- $\alpha$, IL-6, Gene regulation.

\title{
1. Introduction
}

Ghrelin is a 28 amino acids orexigenic hormone produced by X/A-like cells and is well known as the endogenous ligand for growth hormone secretagogue receptor (GHS-R) (Kojima \& Kangawa, 2005). It is produced in the stomach, hypothalamus, pancreas, pituitary, intestine, adrenal gland, testis, ovary, placenta and brain (Silvia \& Kumar, 2010; Yin et al., 2009). Ghrelin has two isoforms, ghrelin and des-Gln14-ghrelin and can be further categorised into two groups, des-acyl ghrelin and acylated ghrelin. Acylated ghrelin is the active form of ghrelin where it is acylated at the third serine residue of the peptide. This modification is essential for the binding of ghrelin to GHS-R in order to exert its effect (Soares \& Moreira, 2008). Des-acyl ghrelin is the form of ghrelin that does not undergo acylation. Ghrelin's main function is to stimulate growth hormone release. Besides, it also regulates food intake, energy homeostasis, adipogenesis and immune system (Kojima \& 
Kangawa, 2005; Soares \& Moreira, 2008).

Ghrelin has been studied in various diseases for its therapeutic role. Moreira and Soares (2007) studied the role of ghrelin in bone, immune system, gastrointestinal tract and cardiovascular system. From their studies on cardiovascular system, ghrelin is shown to inhibit the basal and TNF- $\alpha$-induced chemokines production and mononuclear cell adhesion. This inhibition prevents endothelial dysfunction and inflammation of the cardiovascular system, and thus, ghrelin could be used to treat atherosclerosis and to improve pancreaticobiliary inflammation by inhibiting neutrophil action.

Tumour necrosis factor alpha (TNF- $\alpha$ ) and interleukin 6 (IL-6) are pleiotropic cytokine produced by different immune cells. TNF- $\alpha$ is produced by macrophages, while IL- 6 is produced by T-cells, monocytes and dendritic cells (Coico \& Sunshine, 2009). Many studies have been done to investigate the role ghrelin in the immune system. Most data suggest that ghrelin is involved in regulating the transcription and mRNA expression of pro-inflammatory cytokines, and this implicates that ghrelin has anti-inflammatory effects. According to Dixit and Taub (2005), ghrelin inhibits the production of TNF- $\alpha$ and IL-6 through GHS-R pathway due to the presence of this receptor on the immune cells. There are numerous studies on the effects of ghrelin on cytokines expression, but thus far, no studies have been carried out to investigate the effects of the pro-inflammatory cytokines on ghrelin expression instead. It was hypothesised that the cytokines would decrease the expression of ghrelin for them to exert their pro-inflammatory activities.

\section{Materials and Methods}

\subsection{Cell culture}

The rat pancreatic AR42J cells were purchased from American Type Culture Collection (ATCC, USA) and grown in 4 mL of Nutrient Mixture F-12 Ham (F12K) (Sigma Aldrich, USA) medium supplemented with $20 \%(\mathrm{v} / \mathrm{v})$ of foetal bovine serum (FBS) (i-DNA, Singapore). The cells were maintained and grown in a humid incubator of $5 \%(\mathrm{v} / \mathrm{v}) \mathrm{CO}_{2}$ at $37^{\circ} \mathrm{C}$. The cell culture medium in the tissue culture flask was replaced every three days.

\subsection{Treatment of AR42J Cells with Cytokines}

The cells were allowed to grow until it reached approximately $70 \%$ confluence. Before treatment of cells with cytokines (Millipore, USA), the growth medium was discarded and the cells were washed twice with PBS. Then the cells were pre-incubated one hour with $4 \mathrm{~mL}$ of complete growth medium with reduced amount of heat inactivated- foetal bovine serum (HI-FBS) which was from $20 \%$ to $1 \%$ (v/v) HI-FBS. Following the incubation, the growth medium was discarded and the cells were washed twice with PBS again. Subsequently, different concentration of cytokines were added into the fresh medium supplemented with $1 \%$ FBS. For the control sample, no cytokines were added. The cells were then incubated in a humid incubator of $5 \%(\mathrm{v} / \mathrm{v}) \mathrm{CO} 2$ at $37^{\circ} \mathrm{C}$ for 24 hour.

\subsection{Isolation of Total Cellular RNA, DNase Treatment of RNA and Total Protein Extraction}

The total cellular RNA and total protein were extracted using Tri-Reagent ${ }^{\circledR}$ LS (Molecular Research Center, USA) according to the manufacturer's instruction. Prior to Real-Time PCR, 
the total RNA was DNase treated using RQ1 RNase-Free DNase (Promega, USA) to remove any carried over DNA.

\subsection{Real-Time Reverse Transcriptase-Polymerase Chain Reaction (Real-Time RT-PCR)}

Real-Time PCR was carried out using Quantifast SYBR Green RT-PCR Kit (QIAGEN, Germany) in iCycler iQ5 Real-Time PCR Detection System (Bio-Rad, USA). All reactions were assembled in a final volume of $25 \mu \mathrm{l}$, containing $12.5 \mu \mathrm{l}$ of $2 \mathrm{x}$ Quantifast SYBR Green RT-PCR Master Mix, $1 \mu \mathrm{M}$ of the respective forward and reverse primers, $0.2 \mu \mathrm{l}$ of Quantifast RT-Mix, and a final DNase-treated RNA template amount of $4 \mu \mathrm{g} / \mu \mathrm{L}$. The parameters used for PCR were as follows: $50^{\circ} \mathrm{C}$ for 10 minutes to allow cDNA synthesis, $95^{\circ} \mathrm{C}$ for 5 minutes of Reverse Transcriptase inactivation, followed by 35 cycles of denaturation at $94^{\circ} \mathrm{C}$ for 10 seconds, annealing at $65^{\circ} \mathrm{C}$ for 20 seconds and primer extension at $72^{\circ} \mathrm{C}$ for 30 seconds, before a melt curve analysis was carried out. The quantity of the target mRNA was normalised against a house-keeping gene, $\beta$-actin, which served as an internal control for the determination of the relative mRNA expression of the target gene. PCR primers specific for ghrelin were 5'-CAGAGGACAGAGGACAAGCAGAAGA-3' and 5'-GCTGGATGTGAGTTCTTGCTTAGGA-3' (Lai et al., 2005) and for $\beta$-actin were 5'-TCACCCTGAAGTACCCCATC-3' and 5'-CCATCTCTTGCTCGAAGTCC-3' (Chew et al., 2007).

\subsection{SDS-PAGE and Western Blot Analysis}

A total of $50 \mu \mathrm{g}$ protein samples was size-fractionated on $5-10 \%(\mathrm{w} / \mathrm{v})$ polyacrylamide gels containing SDS under reducing conditions and transferred to Immobilon-P membranes (Milipore, USA) as described by the manufacturer. The PVDF membranes were probed immunochemically with primary antibody diluted to the ratio of 1:1000 and subsequently in secondary antibody (peroxidase-conjugated goat anti-rabbit IgG) (Cell Signaling Technology, USA) diluted to the ratio of 1:2500. Primary antibodies used were anti-ghrelin antibody (Santa Cruz Biotechnology, USA) and anti- $\beta$-actin antibody (AbFrontier, Korea). Immunoreactive bands were visualised and their densities were analysed using the Fluorchem FC2 system (Alpha Innotech, USA).

\subsection{Statistical Analysis}

The online GraphPad Software (GraphPad Software, Inc.) was utilised for statistical analysis. Statistical significance was assessed to determine expression of ghrelin on treated AR42J cells compared to the control (untreated AR42J cells) using a two-tailed, unpaired, Student's-t test. The criterion for statistical significance was $* p<0.05$.

\section{Results}

\subsection{Effects of TNF- $\alpha$ and IL-6 on Ghrelin mRNA Expression}

Generally, the pattern in ghrelin mRNA expression in both TNF- $\alpha$ and IL- 6 treated cells were almost similar (Figure 1). Interestingly, ghrelin mRNA expression was increased by $10 \%$ and $41 \%$ in the concentration of $5 \mathrm{ng} / \mathrm{mL}$ of TNF- $\alpha$ and IL- 6 treated cells, respectively. Subsequently, the ghrelin mRNA was decreased by $10 \%$ and $43 \%$ in TNF- $\alpha$ and IL- 6 treated 
cells as the cytokines concentration was increased to $10 \mathrm{ng} / \mathrm{mL}$, respectively. The lowest mRNA expression was achieved at the concentration of $50 \mathrm{ng} / \mathrm{mL}$ for both cytokines. At this concentration, ghrelin mRNA expression decreased significantly by $45 \%$ in TNF- $\alpha$ treated cell and $80 \%$ in IL-6 treated cells as compared to untreated control. Overall, both cytokines inhibited ghrelin mRNA expression in a dose-dependent manner.

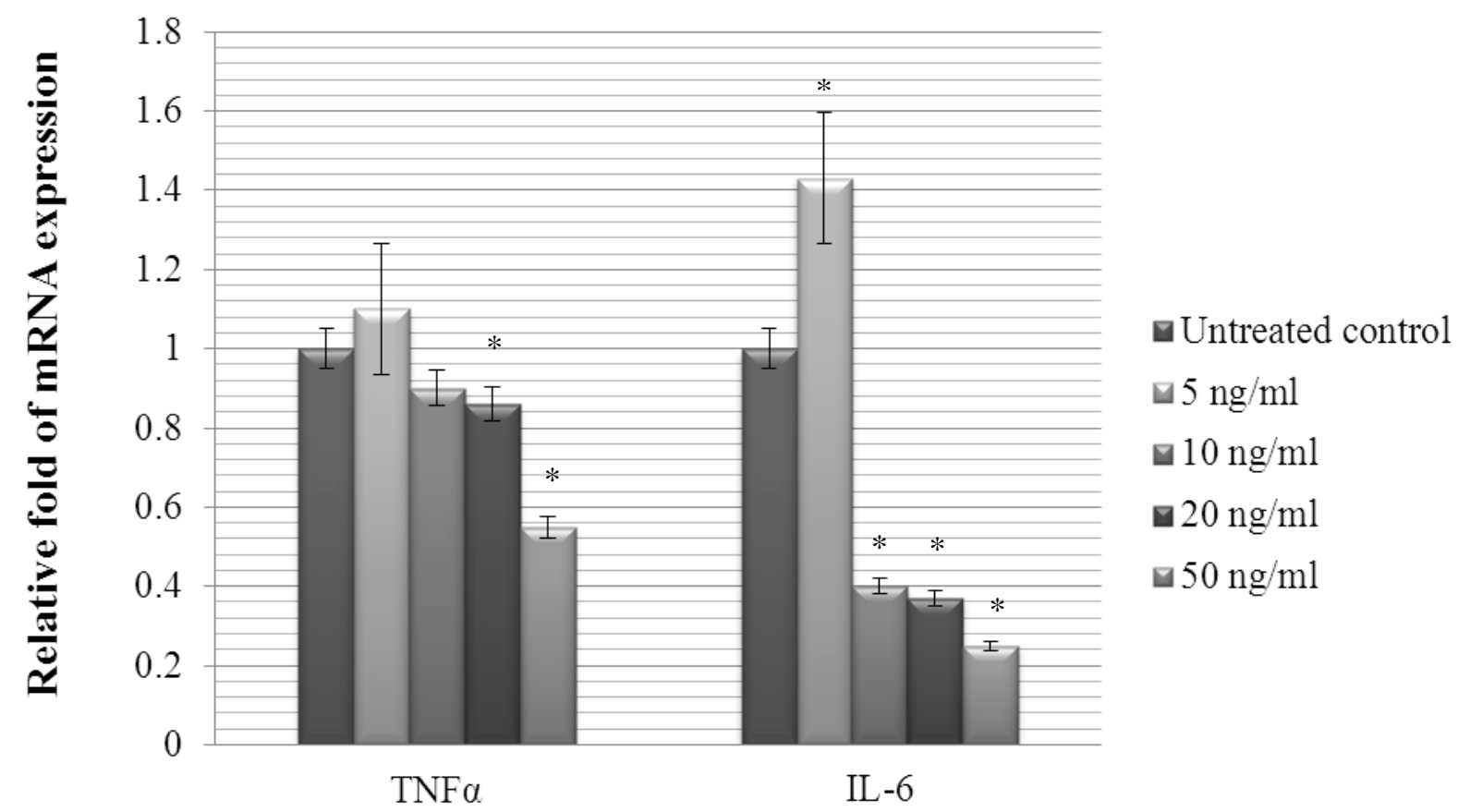

Cytokines

Figure 1. TNF- $\alpha$ and IL-6 downregulated the mRNA expression of ghrelin in higher dose-dependent manner. ${ }^{*} p<0.05$ represents statistically significant change from control (untreated AR42J cells).

\subsection{Effects of TNF- $\alpha$ and IL-6 on Ghrelin protein Expression}

Figure 2(a) shows the immunodetection of ghrelin protein extracted from cells treated with different cytokines. After Western blotting, densitometry anaylsis was performed to quantitatively measure the protein expression (Figure 2(b)). $\beta$-actin was used as housekeeping gene, in which its protein was shown to be expressed constantly and it was not affected by any of the cytokine treatments. From the results, ghrelin protein expression demonstrated similar patterns as the mRNA levels. An increase in density was observed in cells treated with $5 \mathrm{ng} / \mathrm{mL}$ of IL-6. The densities were subsequently decreased as the concentrations of cytokines were increased. At $50 \mathrm{ng} / \mathrm{mL}$ of TNF- $\alpha$ and IL-6, the protein expression was decreased by $22 \%$ and $52 \%$, respectively. Between these two cytokines, IL-6 treatment reduced the ghrelin protein expression significantly as compared to TNF- $\alpha$. 
(a)

$\begin{array}{llllll}\begin{array}{l}\text { Concentration of } \\ \text { cytokines }(\mathrm{ng} / \mathrm{ml})\end{array} & 0 & 5 & 10 & 25 & 50\end{array}$

Cytokine

Protein

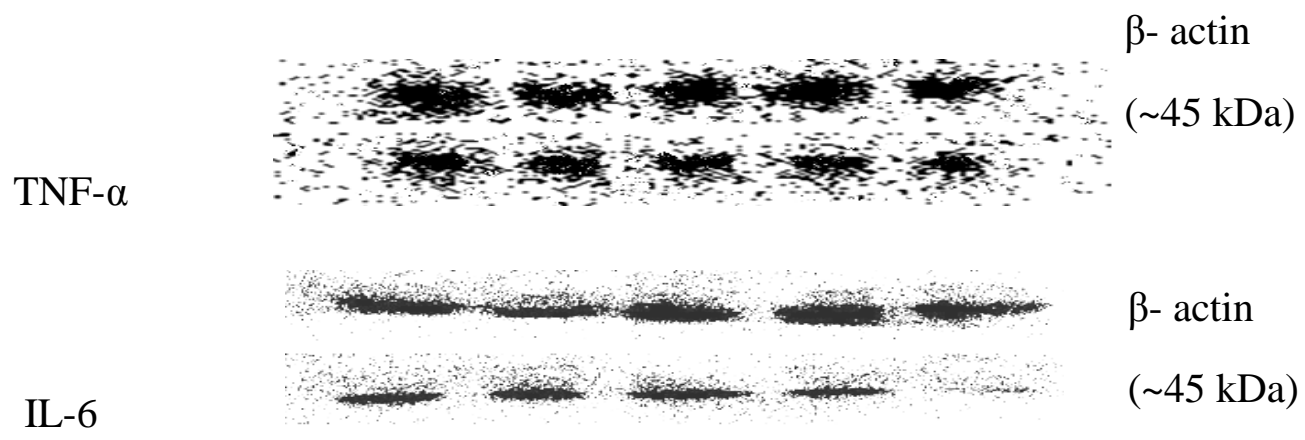

(b)

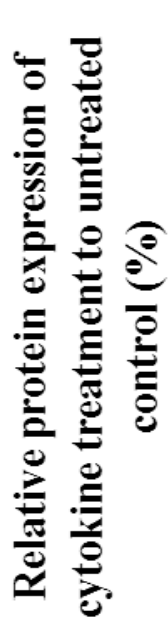

$$
\begin{array}{r}
180 \\
160 \\
140 \\
120 \\
100 \\
80 \\
60 \\
40 \\
20 \\
0
\end{array}
$$

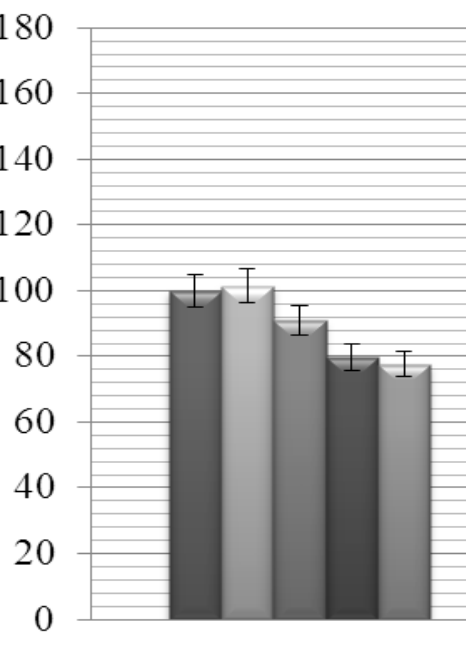

TNF $\alpha$

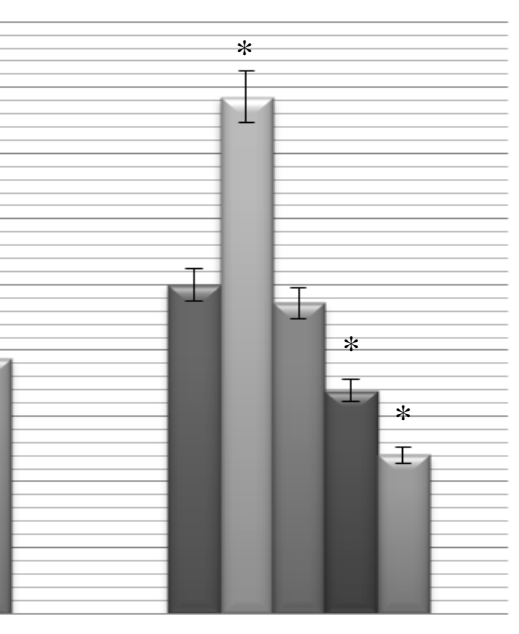

IL-6

- Untreated control $\square 5 \mathrm{ng} / \mathrm{ml}$

$\square 10 \mathrm{ng} / \mathrm{ml}$

$\square 20 \mathrm{ng} / \mathrm{ml}$

$\square 50 \mathrm{ng} / \mathrm{ml}$

\section{Cytokines}

Figure 2. (a) Western blot analyses showed similar downregulated patterns in ghrelin protein expression by TNF- $\alpha$ and IL- 6 , while $\beta$ - actin remained unchanged.

(b) Relative quantified protein expression in cytokine-treated cells relative to untreated control.

\section{Discussion}

The slight increase in ghrelin levels at cytokine concentration of $5 \mathrm{ng} / \mathrm{mL}$ is most probably caused by the increase of the acute phase proteins which its production was stimulated by the cytokines. Ghrelin is an acute phase reactant and its release may assist in restoring 
homeostasis. The anti-inflammatory effect of ghrelin may have caused a slight increase of its expression at low concentration of both these cytokines. The concentration of the cytokine may be too low to exert any effects on the ghrelin gene. At higher concentrations of $10 \mathrm{ng} / \mathrm{mL}$ and above, the effects of the cytokines probably would have overcome the anti-inflammatory effects of ghrelin and this would lead to the subsequent decrease in ghrelin expression. Ghrelin mRNA expression would respond much earlier to the cytokines treatment as compared to their respective protein expression. This shows that the cytokine's inhibitory effect act faster on the mRNA than the protein expression level.

As both TNF- $\alpha$ and IL-6 are pro-inflammatory cytokines, they may share many similar functions and induce similar effects on the host (Gonullu et al., 2005). This could explain the similarities of their action on ghrelin gene expression. One such similar function is both induce insulin resistance in cells. TNF- $\alpha$ is shown to induce insulin resistance by inhibiting insulin-mediated tyrosine phosphorylation on the insulin receptor beta-chains (Gonullu et al., 2005; Ruan \& Lodish, 2003). TNF- $\alpha$ induces serine phosphorylation on insulin receptor substrate-1 (IRS-1) and this impairs insulin signalling. Other mechanisms which TNF- $\alpha$ possesses to impair insulin sensitivity is that it induces lipolysis and increases free fatty acid level which in turn would inhibit insulin signalling through the phosphorylation of insulin signalling protein (Pereira \& Maahs, 2008; Ruan \& Lodish, 2003). During this state, insulin could not exert its effect in promoting glucose uptake and hyperglycaemia would result. This would induce the cell to compensate by increasing the levels of insulin in order to maintain the normal glucose concentration (Ruan \& Lodish, 2003). High levels of IL-6 are shown to stimulate insulin resistance (Deepa et al., 2006; Holmes et al., 2008). Administration of IL-6 into healthy individual by Jiao et al. (2008) showed an increase in insulin resistance, plasma insulin and glucose levels. IL-6 also increases the level of free fatty acids that would impact insulin resistance as the free fatty acids are shown to inhibit insulin signalling (Jiao et al., 2008; Pereira \& Maahs, 2008). The exact mechanism on how IL-6 causes insulin resistance is still not well studied. It is however hypothesised that IL-6 could induce the production of TNF- $\alpha$ as suggested by Gonullu et al. (2005), which would subsequently cause the development of insulin resistance.

The cell line used for this study was the pancreatic cell line, thus insulin could easily be produced by the beta cells of the cell line itself. There are many controversial studies regarding the relationship between ghrelin and insulin. To date, the mechanism of the effects of insulin in regulating ghrelin gene expression remains unknown but studies done by Kamegai et al. (2004) shows that insulin decreases ghrelin gene expression. Besides, Yin et al. (2009) also mentioned that administration of insulin decreases ghrelin levels in humans and rats. According to Kempa et al. (2007), insulin resistance is said to play a more important role in regulating ghrelin gene expression as compared to insulin itself. Therefore, it is hypothesised that IL- 6 and TNF- $\alpha$ inhibits ghrelin gene expression indirectly by increasing insulin level.

In conclusion, there is a dose-response relationship between ghrelin and pro-inflammatory cytokines, TNF- $\alpha$ and IL-6. At high concentrations of cytokines, both ghrelin mRNA and protein expressions are downregulated. The dosages of the cytokines play an important factor 
in the regulation of the ghrelin expression.

\section{Acknowledgement}

The authors thank Ministry of Higher Education for supporting the research under Fundamental Research Grant Scheme (FRGS/1/10/SG/UTAR/03/3(SP)).

\section{References}

Chew, C. H., Chew, G. S., Najimudin, N., \& Tengku-Muhammad, T. S. (2007). Interleukin-6 inhibits human peroxisome proliferator activated receptor alpha gene expression via CCAAT/ enhancer-binding proteins in hepatocytes. The International Journal of Biochemistry \& Cell Biology, 39(10), 1975-1986. http://dx.doi.org/10.1016/j.biocel.2007.05.015

Coico, R., \& Sunshine, G. (2009). Immunology: A Short Course. $\left(6^{\text {th }}\right.$ ed.). New Jersey, USA: Wiley-Blackwell.

Deepa, R., Velmurugan, K., Arvind, K., Sivaram, P., Sientay, C., Uday, S., \& Mohan V. (2006). Serum levels of interleukin-6, C-reactive protein, vascular cell adhesion molecule 1, and monocyte chemotactic protein 1 in relation to insulin resistance and glucose intolerance-the Chennai Urban Rural Epidemiology Study (CURES). Metabolism, 55, 1232-1238. http://dx.doi.org/10.1016/j.metabol.2006.05.008

Dixit, V. D., \& Taub, D. D. (2005). Ghrelin and Immunity: A Young Player in an Old Field. Experimental Gerontology, 40(11), 900-910. http://dx.doi.org/10.1016/j.exger.2005.09.003

Gonullu, G., Ersoy, C., Ersoy, A., Evrensel, T., Basturk, B., Kurt, E., et al. (2005). Relation between insulin resistance and serum concentrations of IL-6 and TNF- $\alpha$ in overweight or obese women with early stage breast cancer. Cytokine, 31, 264-269. http://dx.doi.org/10.1016/j.cyto.2005.05.003

Holmes, A., Neill, Mesa, J., Neill, B., Chung, J., Carey, A., Steinberg, G., et al. (2008). Prolonged interleukin-6 administration enhances glucose tolerance and increases skeletal muscle PPRAa and UCP2 expression in rats. Journal of Endocrinology, 198(2), 367-374. http://dx.doi.org/10.1677/JOE-08-0113

Jiao, K., Liu, H., Chen, J., Tian, D., Hou, J., \& Kaye, A. D. (2008). Roles of plasma interleukin-6 and tumor necrosis factor and FFA and TG in the development of insulin resistance induced by high-fat diet. Cytokine, 42, 161-169. http://dx.doi.org/10.1016/j.cyto.2007.12.002

Kamegai, J., Tamura, H., Shimizu, T., Ishii, S., Sugihara, H., \& Oikawa, S. (2004). Effects of insulin, leptin, and glucagon on ghrelin secretion from isolated perfused rat stomach. Regulatory Peptides, 119(1-2), 77-81. http://dx.doi.org/10.1016/j.regpep.2004.01.012

Kempa, A., Krzyzanowaka-Swiniarska, B., Miazgowski, T., \& Pilarska, K. (2007). Not insulin but insulin sensitivity, leptin and cortisol are major factors regulating serum acylated ghrelin in healthy women. Journal of Endocrinological Investigations, 30(8), 659-665. PMid:17923797 
Krzyzanowska-Swiniarska, B., Kempa, A., Miazgowski, T., Pilarska, K. (2007). Serum acylated ghrelin, adiponectin and leptin levels in normal-weight and obese premenopausal women. Hormone and Metabolic Research, 39(11), 835-839. http://dx.doi.org/10.1055/s-2007-991175

Kojima, M., \& Kangawa, K. (2005). Ghrelin: Structure and Function. Physiological Reviews, 85, 495-522. http://dx.doi.org/10.1152/physrev.00012.2004

Lai, J. K. C., Cheng, C. H. K., Ko, W. H., \& Leung, P. S. (2005). Ghrelin system in pancreatic AR42J cells: its ligand stimulation evokes calcium signaling through ghrelin receptors. The International Journal of Biochemistry \& Cell Biology, 37, 887-900. http://dx.doi.org/10.1016/j.biocel.2004.11.012

Moreira, A. F. L., \& Soares, J. B. (2007). Physiological, pathological and potential therapeutic roles of ghrelin. Drug Discovery Today, 12(7/8), 276-288. http://dx.doi.org/10.1016/j.drudis.2007.02.009

Pereira, R. I., \& Maahs, D. M. (2008). Mediators of insulin resistance. In P. S. Zeitler and K. J. Nadeau (Eds.), Insulin Resistance: Childhood Precursors and Adult Disease (1 ${ }^{\text {st }}$ ed., pp. 161-178). New Jersey, USA: Humana Press.

Ruan, H., \& Lodish, H. F. (2003). Insulin resistance in adipose tissue: direct and indirect effects of tumor necrosis factor- $\alpha$. Cytokine \& Growth Factor Reviews, 14, 447-455. http://dx.doi.org/10.1016/S1359-6101(03)00052-2

Silvia, W. D., \& Kumar, B. (2010). Saga of Ghrelin: its structure, actions, and therapeutic uses. Asian Biomedicine, 4(6), 855-860.

Soares, J. B, \& Leite-Moreira, A. F. (2008). Ghrelin, Des-acyl Ghrelin and Obestation: Three Pieces of the Same Puzzle. Peptides, 29, 1255-1270. http://dx.doi.org/10.1016/j.peptides.2008.02.018

Yin, X. F., Li, Y., Xu, G. Y., An, W. J, \& Zhang, W. Z. (2009). Ghrelin Fluctuation, What Determines Its Production? Acta Biochimica et Biophysica Sinica, 41(3), 188-197. http://dx.doi.org/10.1093/abbs/gmp001

\section{Copyright Disclaimer}

Copyright reserved by the author(s).

This article is an open-access article distributed under the terms and conditions of the Creative Commons Attribution license (http://creativecommons.org/licenses/by/3.0/). 